\title{
Yield Gap Analysis of Utera Cropping of Linseed in Rice-Fallow Areas
}

\author{
B. Gogoi ${ }^{1 *}$, S. Bhagowati ${ }^{2}$ and N. Deka ${ }^{1}$ \\ ${ }^{1}$ Krishi Vigyan Kendra, Nagaon, AAU, Simaluguri, Assam, India \\ ${ }^{2}$ Horticultural Research Station, Kahikuchi, Kamrup, Assam, India \\ *Corresponding author
}

\section{A B S T R A C T}

\begin{tabular}{l} 
Ke y w or d s \\
Linseed, Utera, \\
Yield gap, \\
Technology gap, \\
Extension gap, \\
Technology index \\
\hline Article Info \\
\hline $\begin{array}{l}\text { Accepted: } \\
\text { 14 May 2020 } \\
\text { Available Online: } \\
\text { 10 June } 2020\end{array}$ \\
\hline
\end{tabular}

In India, monocropping is a major drawback. This is also a holding back situation for low yielding states like Assam where monocropping accounts for approximately $46 \%$ of total cultivated rice area. This rice fallow can effectively and efficiently be utilized for increasing farm income through utera cropping. In order to find the thrust area of linseed under rice utera condition, a study was conducted in large blocks in a participatory mode in farmers' field of Nagaon district of Assam in the year 2016-17 and 2017-18 with 103 numbers of demonstrations in 40 ha of land. The treatments were rice-linseed utera cropping with recommended practices compared with farmers practices in rice monocrop as check. Different yield attributing characters during demonstration and farmers' practice were recorded and their yield gap, technology gap, extension gap and technology index were analyzed accordingly. The yield of linseed in Rice-L inseed cropping system reported 15.7 to 35.2 per cent higher over farmers' monocrop system. On an average technology gap was recorded to be $3.55 \mathrm{q} / \mathrm{ha}$. While average extension gap was observed to be 5.75 $\mathrm{q} /$ ha. Average technology index was recorded as 29.58 per cent.

\section{Introduction}

As it is known to us that rice is one of the major cereal crops of India and the most important staple food crop. Asia contribute 90 per cent of its production. In Assam the winter rice occupies an area of 17.99 lakh ha with the productivity of $1993 \mathrm{~kg} / \mathrm{ha}$ (AAU Newsletter, 2013). But there is a major problem of keeping these rice cultivated area fallow after their harvest in many pockets of Assam as well as the country during the rabi season. Keeping in mind the forever increasing population and decreasing agricultural lands due to industrialization, vertical and horizontal expansion of land for agricultural purpose to mitigate the food grain demand of the country.

Utera cropping is one of a technique which helps in sustainable utilization of all the resources (Bhowmick, 2008). The system of utera may vary from one place to other depending upon the prevailing agroclimatic situation of a region. So it is very important to study and identify a suitable cropping system under rice utera for sustaining land productivity as well as human consumption to 
make the system more viable, feasible and profitable for our farmers. Therefore, anagro technological intervention through introduction of utera cropping is becoming very essential to improve productivity under rice based cropping system. So, keeping in view the importance of these fallow areas, a very important crop Linseed (Linum usitatissimum) was demonstrated in farmer's field asrabi oilseed after harvesting of winter paddy in the year 2016-17 and 2017-18. Its importance and potentiality to be adopted as an economical crop in rice fallow has been well marked because of its ability to grow even in marginal and poor exhausted soils. In the present study, performance of linseed under rice fallow was evaluated in cluster frontline demonstration conducted at farmers' field during rabi seasons for two years.

\section{Materials and Methods}

The study to evaluate the economic advantages of rice linseed utera, KrishiVigyan Kendra, Nagaon, Assam conducted Cluster frontline demonstration with 103 farmers of 7 different villages of Nagaon district covering an area of 40 ha for two years. The FLD's were conducted to study the gap between potential yield (12 q/ha), demonstration yield, extension gap and technology index.

An improved variety T 397 of Linseed was used with incorporation of following improved technology like seed treatment with Azospirillum and PSB biofertilizer @ 50g per $\mathrm{kg}$ of seed and half of the recommended fertilizer dose $\left(20: 10: 5 \mathrm{~kg} / \mathrm{ha}\right.$ of $\left.\mathrm{N}: \mathrm{P}_{2} \mathrm{O}_{5}: \mathrm{K}_{2} \mathrm{O}\right)$ were applied in demonstration plots and comparison was made with the sole crop(Table 1) of linseed considering it as farmer's practice (check). The rice equivalent yield data from the demonstration and monocropping practice were recorded and their technology gap, extension gap and the technology index were worked out using methods developed by Samui et al., (2000) as stated below:

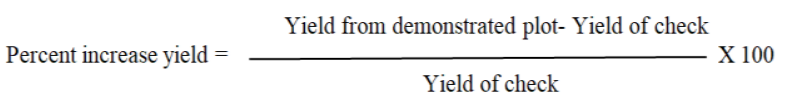

Technology gap = Potential yield of crop Yield from demonstrated plot

Extension gap $=$ Yield from demonstrated plot- yield under existing practice

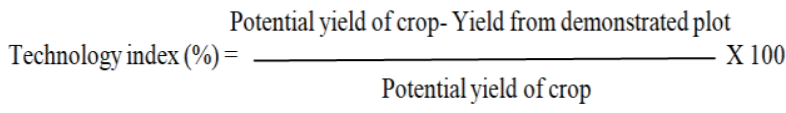

The rice equivalent yield was computed by multiplying the grain yield of linseed with the price per unit. The calculated total return was divided by the price of rice and was added to the rice grain yield.

\section{Results and Discussion}

\section{Yield performance}

Yield is a major component of any cropping system since it will show the profitable component only if the farmer can earn more through his yield. The results of demonstrations for two years revealed that rice equivalent yield of 58.23 and $64.7 \mathrm{q} / \mathrm{ha}$ was obtained during 2016-17 and 2017-18, respectively, which were found 15.7 to 35.2 percent consequently, increased over monocrop rice.

Data further showed that the rice equivalent yield in the year 2016-17 and 2017-18 was increased successively which clearly speaks of the positive impact of cluster front line demonstration over monocrop rice field (Table1). This response of linseed under rice fallow was also found to be similar with the research finding of Bora et al., (2018). 


\section{Technology gap}

A technology gap is a situation when a farmer is unaware about the recommended set of technologies also recommended for the crop. That gap is being analyzed using the technology gap. The results showed that the technological gap (6.77 and $0.3 \mathrm{q} / \mathrm{ha})$ in the year 2016-17and 2017-18, respectively reflected the farmer's cooperation, in carrying out such demonstrations (Table 1). As mentioned by Bora et al., (2018), the he technology gap observed may be attributed to variability in the soil fertility and climatic conditions.

So use of proper recommendations can help in increasing the income. During the period of study, an average of $3.55 \mathrm{q} / \mathrm{ha}$ extension gaps was recorded which gives a scenario that we need to emphasize more on educating the farmers through utilizing the various means which can help them in adoption of recent and improved agricultural technologies.

Table.1 Productivity, technology gap, technology index and extension gap of utera crop linseed in rice fallow and monocrop rice as check

\begin{tabular}{|c|c|c|c|c|c|c|}
\hline Year & $\begin{array}{l}\text { Average Rice } \\
\text { equivalent } \\
\text { yield(q/ha) }\end{array}$ & $\begin{array}{l}\text { Yield } \\
\text { of farmer's } \\
\text { practice } \\
\text { (q/ha) }\end{array}$ & $\begin{array}{l}\text { Increase over } \\
\text { monocrop } \\
\text { practice }(\%)\end{array}$ & $\begin{array}{l}\text { Extension } \\
\text { gap (q/ha) }\end{array}$ & $\begin{array}{l}\text { Technolog } \\
\text { y gap } \\
\text { (q/ha) }\end{array}$ & $\begin{array}{l}\text { Technolog } \\
\mathbf{y} \text { index } \\
(\%)\end{array}$ \\
\hline 2016-17 & 58.2 & 52.4 & 15.7 & 5.78 & 6.77 & 10.41 \\
\hline 2017-18 & 64.7 & 58.9 & 35.5 & 5.72 & 0.3 & 0.46 \\
\hline
\end{tabular}

Table.2 Economic returns from rice linseed uteracrop under FLD with monocrop rice

\begin{tabular}{|l|l|l|l|l|l|l|l|l|}
\hline \multirow{2}{*}{ Year } & \multicolumn{2}{l}{$\begin{array}{l}\text { Cost of cultivation } \\
\text { (Rs/ha) }\end{array}$} & \multicolumn{2}{l|}{$\begin{array}{l}\text { Gross Return } \\
\text { (Rs/ha) }\end{array}$} & \multicolumn{2}{l|}{$\begin{array}{l}\text { Net Return } \\
\text { (Rs/ha) }\end{array}$} & \multicolumn{2}{l|}{ B:C ratio } \\
\cline { 2 - 10 } & Demo & Check & Demo & Check & Demo & Check & Demo & Check \\
\hline $\mathbf{2 0 1 6 - 1 7}$ & 32430 & 31000 & 96483 & 86803 & 64053 & 55803 & 1.98 & 1.78 \\
\hline $\mathbf{2 0 1 7 - 1 8}$ & 32430 & 31000 & 103600 & 83690 & 71170 & 52690 & 2.20 & 1.69 \\
\hline
\end{tabular}

\section{Technology index}

A technology is feasible of not can be assessed through the technology index. The lowest values of technology index indicate the more feasibility of the technology. So the results of the demonstration showed a decrease in the technology index from 10.41 to 0.46 per cent indicated that the demonstrated technology was feasible (Table.1) as mentioned by Bora et al., (2018).

\section{Benefit: cost ratio}

The economics of any cropping system calculated out through assessment of Benefit to cost ratio. The demonstration of two years resulted that $\mathrm{B}: \mathrm{C}$ ratio from recommended practice were comparatively higher than the farmers practice during both the years of the demonstration (Table 2). The average net return/ha from the demonstration was Rs. 64,023.00 and Rs.71, 170.00 per ha while from the local check Rs.55, 803.00 and Rs. $52,690.00$ per ha in during the 2016-17 and 2017-18, respectively. The benefit cost ratio of demonstration and local check were observed to be $1.98,2.20$ and $1.78,1.69$ during 2016-17 and 2017-18, respectively. There is a need in shift of traditional agriculture to conventional agriculture to sustain the yield and also to meet the food 
requirement of the world to combat the hunger crises. Along with the need of food, a balanced diet is also to be taken into consideration for balancing the nutrition sensitive agriculture. Linseed is a rich source of fiber and many vitamins and minerals which can fulfill the body requirements. Linseed in utera system can help in proper utilization of all natural and available resources of the farmer's field and also it can give a scope towards vertical expansion in agriculture.

\section{References}

AAU Newsletter. (2013). Assam Agricultural University, Jorhat, Assam, AAU
Printing press.

Bhowmick, M. K. (2008). Effect of foliar nutrition and basal fertilization in lentil under rainfed conditions. J. Food Legumes, 21: 115-16.

Bora, S.K, Saud, R.K. and Thakuria, K. (2018). Production potential of linseed (Linum usitatissimum) in rice fallows under rainfed condition. Agric. Sci. Digest. 38 (2) : 143-145

Samui, S. K.; Mitra, S.; Roy, D. K.; Mandal, A. K. and Saha, D. (2000). Evaluation of front line demonstration on groundnut. Journal of the Indian Society Costal Agriculture Research.18(2):180183.

\section{How to cite this article:}

Gogoi. B., S. Bhagowati and Deka. N. 2020. Yield Gap Analysis of Utera Cropping of Linseed in Rice-Fallow Areas. Int.J.Curr.Microbiol.App.Sci. 9(06): 181-184.

doi: https://doi.org/10.20546/ijcmas.2020.906.024 